9. Jarrell, K. F., Bayley, D. P. \& Kostyukova, A. S. (1996) The archaeal flagellum: a unique motility structure. $J$ Bacteriol 178, 5057-5064.

10. Jones, C. J. \& Aizawa, S. (1991). The bacterial flagellum and flagellar motor: structure, assembly and function. Adv Microb Physiol 32, 109-172.

11. Kalmokoff, M. L. \& Jarrell, K. F. (1991). Cloning and sequencing of a multigene family encoding the flagellins of Methanococcus voltae. J Bacteriol 173, 7113-7125.

12. Kawarabayasi, Y., Sawada, M., Horikawa, H. \& 22 other authors (1998). Complete sequence and gene organization of the genome of a hyper-thermophilic archaebacterium, Pyrococcus horikoshii OT3. DNA Res $5,55-76$.

13. Klenk, H.-P., Clayton, R. A., Tomb, J.-F. \& 48 other authors (1997). The complete genome sequence of the hyperthermophilic, sulphate-reducing archaeon Archaeoglobus fulgidus. Nature 390, 364-370.

14. Le Moual, H. \& Koshland, D. E., Jr (1996).

Molecular evolution of the C-terminal cytoplasmic

domain of a superfamily of bacterial receptors involved

in taxis. J Mol Biol 261, 568-585.

15. Lechner, J., Wieland, F. \& Sumper, M. (1985)

Transient methylation of dolichyl oligosaccharides is an obligatory step in halobacterial sulfated glycoprotein biosynthesis. J Biol Chem 260, 8984-8989.

16. Rosario, M. M., Kirby, J. R., Bochar, D. A. \& Ordal, G. W. (1995). Chemotactic methylation and behavior in Bacillus subtilis: role of two unique proteins, CheC and CheD. Biochemistry 34, 3823-3831.

17. Rudolph, J. \& Oesterhelt, D. (1995). Chemotaxis and phototaxis require a CheA histidine kinase in the archaeon Halobacterium salinarium. EMBO J 14, 667-673.

18. Smith, D. R., Doucette-Stamm, L. A., Deloughery, $\& 22$ other authors (1997). Complete genome sequence of Methanobacterium thermoautotrophicum deltaH:

functional analysis and comparative genomics.

Bacteriol 179, 7135-7155.

19. Wright, E. L., Deakin, W. J. \& Shaw, C. H. (1998)

GenBank accession no. AF044495.

\section{ISP-4 and CWBP52 are proteins encoded by the same gene in Bacillus subtilis}

One of the expected benefits of genome sequencing efforts is to allow unification of sometimes disparate observations from labs focused on different biochemical or physiological questions. One of us (R.L.S.) has previously partially purified and characterized a serine proteinase from Bacillus subtilis cells, which appeared to be an intracellular enzyme. The proteinase had several distinguishing properties and was designated Intracellular Serine Protease-4 or ISP-4 (4). The major protein band observed on detergent-loaded electrophoretic gels had an apparent molecular mass of $43 \mathrm{kDa}$; amino acid sequencing of this protein yielded an unambiguous nonapeptide at its amino terminus. A recent search of the SubtiList database of protein sequences revealed that this peptide had an identity at eight positions with the amino terminus of a cell-wall-

Table 1. Comparison of proteinases ISP-4 and CWBP52

Property

Hydrolysis of azocasein

Hydrolysis of azocoll

Stimulation by calcium ions

Inhibition by PMSF

Sequence of amino terminus

SDS gel molecular mass $(\mathrm{kDa})$

Isoelectric point

Growth and sporulation in strain missing activity

associated protein, CWBP52, which Margot \& Karamata recently demonstrated has proteinase activity against azocasein (1). A comparison of these two proteinases is given in Table $1(1,4,5)$.

Margot \& Kamarata (1) have shown that the CWBP52 proteinase is cleaved from a larger $96 \mathrm{kDa}$ WprA protein and contains the conserved aspartate/histidine/serine catalytic triad typical of the B. subtilis serine proteinase subtilisin and the major intracellular serine proteinase-l, ISP-1 (3). Although Margot \& Kamarata (1) did not report any effects of calcium ions on the proteinase activity of CWBP52, we point out here that two critical side chains involved in the strong calcium binding site of subtilisin (2) are conserved in the sequence reported for CWBP52 [residues D471 and N511 in Fig. 3 of reference (1)].

Because extremely high salt concentrations ( $3 \mathrm{M}$ ) were necessary to strip the CWBP52 protein from the cell walls, it is easy to understand how Sheehan \& Switzer (4) were led to believe that ISP-4 was an intracellular protein rather than the cell-wallassociated protein it appears to be $(1,5)$. Initial steps in the purification of ISP-4 yielded active fractions with apparent molecular masses of 8-10 MDa; even after several chromatographic steps, the active protein had an apparent molecular mass of about $400 \mathrm{kDa}$. However, electrophoresis on SDS gels of the most purified protein revealed the presence of multiple protein bands. The difficulty that these workers experienced in trying to separate the ISP-4 activity from other proteins (perhaps from cell wall proteins) might be explained by the extremely alkaline $\mathrm{pI}$ of this protein. Whether the apparently smaller ISP-4 $(43 \mathrm{kDa})$ is a further processed portion of CWBP52 $(52 \mathrm{kDa})$ will require further study.

If, as seems probable to us, these two proteinases are encoded by the same gene, several features of these two lines of inquiry can be explained and tested for in the future.
Proteinase
ISP-4

$+$

Weak

$+$

$+$

NDKQYPYQ

43

Not reported

Normal

\section{CWBP52}

$+$

Not reported Not reported but expected

ANDIQYPYQ

$52-55$

9.9

Normal
First, since the B. subtilis strain from which an active ISP-4 was isolated contained deletions in the two major extracellular proteinases [products of the $a p r$ and $n p r E$ genes; see ref. (3)], we infer that neither of these proteinases are required for the cleavage of the $96 \mathrm{kDa}$ WprA precursor protein to release the active cell-wall-bound proteinase, ISP-4/CWBP52. Second, since a strain lacking ISP-1 failed to produce an active ISP-4 (4), it seems probable that ISP-1 plays a role in the proteolytic processing of the $96 \mathrm{kDa}$ WprA to yield CWBP52/ISP-4 in active forms.

\section{James H. Hageman' and Robert L. Switzer ${ }^{2 *}$}

'Department of Chemistry and Biochemistry, Box 30001, New Mexico State University, Las Cruces, NM 88003, USA

'Department of Biochemistry, 419 Roger Adams Laboratory, $600 \mathrm{~S}$. Mathews Avenue, University of Illinois at Urbana-Champaign, Urbana, IL 61801, USA

*For correspondence: Tel: +1 2173333940.

Fax: +1 2172445858

e-mail: rswitzer@uiuc.edu

1. Margot, P. \& Karamata, D. (1996). The wprA gene of Bacillus subtilis 168 , expressed during exponential growth, encodes a cell-wall-associated protease. Microbiology 142, 3437-3444.

2. McPhalen, C. A. \& James, M. N. G. (1988). Structural comparison of two serine proteinase-protein inhibitor complexes: eglin-subtilisin Carlsberg and CI-2-subtilisin Novo. Biochemistry 27, 6582-6598.

3. Pero, J. \& Sloma, A. (1993). Proteases. In Bacillus subtilis and Other Gram-Positive Bacteria, pp. 939-952. Edited by A. L. Sonenshein, J. A. Hoch \& R. Losick. Washington, DC: American Society for Microbiology.

4. Sheehan, S. M. \& Switzer, R. L. (1991). Intracellular serine protease-4, a new intracellular serine protease activity from Bacillus subtilis. Arch Microbiol 156, 186-191.

5. Studer, R. E. \& Karamata, D. (1988). Cell wall proteins in Bacillus subtilis. In Antibiotic Inhibition of Bacterial Cell Surface Assembly and Function, pp. 146-150. Edited by P. Actor, L. Daneo-Moore, M. L. Higgins, M. P. Salton \& G. D. Shockman. Washington, DC: American Society for Microbiology. 